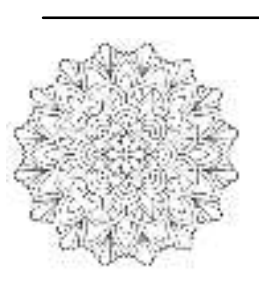

AL HIKMAH: INDONESIAN JOURNAL OF EARLY CHILDHOOD ISLAMIC EDUCATION

ISSN (P): 2550-2200, ISSN (E): 2550-1100,

VOL. 4 (2), 2020, PP. 97 - 108

http://journal.iaialhikmahtuban.ac.id/index.php/ijecie

\title{
PENERAPAN FOCUSED STIMULATION DALAM KEMAMPUAN BAHASA RESEPTIVE PADA ANAK RETARDASI MENTAL DI RUMAH SAKIT JIWA TAMPAN PEKANBARU
}

\author{
Alucyana $^{1}$, Ida Windi Wahyuni ${ }^{2}$ Dian Tri Utami ${ }^{3}$ \\ ${ }^{1,2,3}$ Pendidikan Islam Anak Usia Dini, Fakultas Agama Islam, Universitas Islam Riau \\ alucyana@fis.uir.ac.id \\ Abstrak
}

\begin{abstract}
Penelitian ini bertujuan ingin melihat Penerapan Metode Focused Stimulation dalam meningkatkan kemampuan Bahasa Reseptive pada anak Retardasi Mental di Rumah Sakit Jiwa Tampan Pekanbaru. Subjek dalam penelitian ini berjumlah 3 orang dengan kriteria mengalami Mental Retardasi dan perkembangan Bahasa Reseptive yang rendah. Pelaksanaan penerapan Metode Focused Stimulation di laksanakan sebanyak 10 kali sesi, termasuk di dalamnya hasil baseline dan evaluasi setelah penerapan. Dari hasil penerapan metode terlihat peningkatan pemahaman bahasa reseptive pada subjek. Peningkatan ini dapat dilihat dari hasil baseline dan evaluasi. Pada subjek FA terjadi peningkatan yakni hasil baseline mendapatkan nilai 3 poin dan nilai evaluasi menjadi 5 poin,ini artinya terjadi peningkatan 2 poin. Pada subjek FR terjadi peningkatan yakni hasil baseline mendapatkan nilai 4 poin dan nilai evaluasi menjadi 7 poin,ini artinya terjadi peningkatan 3 poin. Pada subjek FM terjadi peningkatan yakni hasil baseline mendapatkan nilai 5 poin dan nilai evaluasi menjadi 8 poin,ini artinya terjadi peningkatan 3 poin. Dengan demikian dapat dikatakan bahwa Metode Focused Stimulation efektif untuk peningkatan bahasa reseptive pada anak Retardasi Mental.
\end{abstract}

Kata Kunci: Focused Stimulaion, Bahasa Reseptive, Retardasi Mental

Abstract

This study aims to see the application of the Focused Stimulation Method in improving the ability of prescription language in children with mental retardation at Tampan Mental Hospital Pekanbaru. The subjects in this study were 3 people with the criteria of experiencing low mental retardation and prescription language development. The implementation of the Focused Stimulation Method was carried out for 10 sessions, including baseline results and evaluation after implementation. From the results of the application of the method shows an increase in understanding of the receptive language on the subject. This increase can be seen from the baseline and evaluation results. In the FA subject there was an increase, namely the baseline results got 3 points and the evaluation score became 5 points, this means that there was an increase of 2 points. In the FR subject there was an increase, namely the baseline results got a value of 4 points and the evaluation value was 7 points, this means that there was an increase of 3 points. In the FM subject there was an increase, namely the baseline results got 5 points and the evaluation score became 8 points, this means that there was an increase of 3 points. Thus it can be said that the Focused Stimulation Method is effective for improving receptive language in children with mental retardation

Keywords Focused Stimulation, Reseptive Language, Mental Retardation 


\section{PENDAHULUAN}

Anak merupakan aset negara. Pada pundak mereka memikul tanggung jawab dan kelangsungan kehidupan negara dan bangsa. Anak adalah pemilik masa kini dan masa depan bangsa dan sekaligus pemilik bangsa, karena di tangan merekalah di teruskan sejarah kehidupan manusia (Mukhtar Latif, dkk, 2013). Semua orangtua ingin memiliki anak yang sehat, baik secara fisik maupun mental, namun pada kenyataannya beberapa orangtua di takdirkan memiliki anak berkebutuhan khusus (ABK), salah satunya $A B K$ dengan jenis Retardasi Mental (RM).

Anak dengan Retardasi Mental juga di sebut anak Tunagrahita yang mempunyai fungsi intelektual dibawah rata - rata (70) yang muncul bersamaan dengan kurangnya perilaku adaptif, ketidakmampuan beradaptasi dengan kehidupan sosial sesuai tingkat perkembangan dan budaya, sebelum usia 18 tahun (Wong 2004). Anak RM mengalami keterbatasan sosialisasi dikarenakan tingkat intellegensianya yang rendah, sehingga cukup sulit untuk mempelajari informasi dan keterampilan - keterampilan menyesuaikan diri dengan lingkungan (Soetjiningsih 1998).

Keterbelakangan mental adalah kecacatan yang ditandai oleh keterbatasan yang signifikan baik dalam fungsi intelektual maupun dalam perilaku adaptif sebagaimana dinyatakan dalam keterampilan adaptif konseptual, sosial, dan praktis ( Minakshi Vashist, dkk , 2011). Sedangkan Wennar (2006) mendifinisikan Retardasi Mental (RM) adalah : mempunyai tiga kriteria di bawah ini: (1) inteligensi dibawah rata-rata, (2) deficit (kerusakan) perilaku adaptive; dan (3) muncu dibawah usia 18 tahun. ( kriteria DSM-IV). Dengan demikian dapat disimpulkan bahwa anak yang mengalami retardasi mental adalah anak yang mengalami intelektual deficit dan ketidakmampuan dalam menyesuaikan diri dalam berinteraksi social.

Mental Retardasi adalah suatu kondisi yang sangat heterogen yang mungkin dihasilkan dari baik non-genetik (seperti keracunan ibu, prematur, iskemia, atau penyakit menular) dan faktor genetik yang secara keseluruhan mempengaruhi fungsi kognitif. MR yang diwariskan adalah umumnya dikategorikan sebagai non-sindrom. Kendati beragam, faktor genetik berkontribusi pada MR (Kaufmann dan Moser 2000; Fiala et al. 2002; Newey et al.2005 dalam Oliver von Bohlen und Halbach, 2010) 
Dengan keterbatasan tersebut, anak mental retardasi akan menimbulkan masalah bagi masyarakat, keluarga maupun pada individu penyandangnya, (Somantri 2007). Keterbatasan yang paling umum pada anak menal retardasi adalah keterlambatan dalam perkembangan bahasa, baik kemampuan bahasa reseptive maupun ekspresif. Padahal bahasa merupakan alat penting untuk melakukan interaksi dimasyarakat. Gorys Keraf (dalam Husain Junus, 1996) menyatakan bahwa "Bahasa adalah alat komunikasi antar anggota masyarakat yang berupa bunyi suara atau tanda atau lambang yang dikeluarkan oleh manusia untuk menyampaikan isi hatinya kepada manusia lainnya".

Menurut Paul Fletcher dan Jon F. Miller (2005) pada anak anak yang mengalami disablitas perkembangan memiliki sindrom otak unik yang terkait dengan gangguan perkembangan spesifik yang menyebabkan kesulitan tertentu dengan pembelajaran dan penggunaan bahasa. Dalam sebuah penelitian menemukan bahwa bahasa umumnya mengikuti perkembangan usia mental (Bates 2004; Reilly, Losh, Bellugi, \& Wulfeck 2004 dalam Paul Fletcher dan Jon F. Miller 2005). Pada anak anak Retardasi Mental biasanya usia kronologisnya (CA) tidak sesuai dengan usia mentalnya (MA). Mereka yang memiliki kelainan fungsi otak dan bicaranya, tentu mempunyai kesulitan dalam berbahasa, baik reseptif maupun produktif. Inilah yang disebut sebagai gangguan berbahasa (Rohmani Nur Indah, 2017).

Dengan demikian terlihat bahwa anak retardasi mental, selain mengalami hambatan dalam fungsi intelektual, juga mengalami hambatan dalam berkomunikasi yaitu kemampuan bahasa, baik bahasa reseptive maupun bahasa ekpresif. Beberapa metode telah dikenal untuk meningkatkan kemampuan bahasa reseptive pada anak retardasi mental, salah satunya adalah dengan metode Focused Stimulation. Menurut Rhea Paul (2012) pada metode focused stimulation ini mengatur konteks interaksi sehingga anak anak tergoda untuk menghasilkan ucapan yang telah ditargetkan. Anak anak dibantu dengan menyediakan model model target yang ditentukan dalam konteks komunikatif yang bermakna, biasanya dilakukan berupa permainan. pendekatan ini sangat efektif untuk meningkatkan pemahaman bentuk, serta produksi (Weismer \& Robertson, 2006 dalam Rhea Paul 2012).

Pada pelaksanaanya terapis / guru memberikan beberapa contoh dari bentuk target dalam konteks bermain terstruktur tetapi interaktif. Perhatikan bagaimana guru pertama memberikan kesempatan bagi klien untuk melakukan kegiatan, tetapi ketika anak merespon ragu-ragu, kemudian melanjutkan untuk memberikan model lanjut. Terapis/ guru 
memberikan umpan balik yang mirip dengan ekspansi ketika anak membuat usaha yang gagal. Dia meminta untuk mencoba bentuk, tetapi jika anak menolak untuk melakukannya terapi hanya berlangsung memberikan model tambahan" ( Weisner \& Robertson. 2006 dalam Rhea Paul 2012 )

Berdasarkan permasalahan diatas, Penelitian ini sangat penting untuk dilakukan karena salah satu yang menjadi hambatan anak anak Retardasi Mental (RM) untuk diterima di masyarakat adalah minimnya kemampuan berbahasa (baik reseptive maupun ekspresif) sehingga menghambat mereka untuk berinterakasi dan bersosialisasi ditengah masyarakat.

Adapun yang menjadi rumusan dan tujuan dari penelitian ini adalah bagaimana penerapan metode focused simulation untuk kemampuan bahasa reseptive pada anak retardasi mental, sehingga dengan penerapan tersebut pemahaman bahasa reseptive anak retardasi mental menjadi lebih baik lagi.

\section{METODE}

Metode penelitian yang digunakan dalam penelitian ini adalah metode penelitian kualitatif. Pendekatan kualitatif dipandang lebih sesuai digunakan untuk mengetahui bagaimana penerapan focused stimulation dalam kemampuan bahasa reseptive pada anak retardasi mental. Hal ini disebabkan penggunaan metode kualitatif memungkinkan peneliti untuk mengetahui lebih jelas bagaimana proses dan hasil penerapan focused stimulation dalam kemampuan bahasa resptive anak retardasi mental melalui cara deskripsi dalam bentuk kata-kata, bahasa, perilaku pada suatu konteks khusus yang alamiah dan memanfaatkan berbagai metode pengambilan data.

Metode pengambilan data dalam penelitian ini adalah dengan observasi, wawancara dan hasil tes psikologi. Responden dipilih dalam penelitian berdasarkan beberapa kriteria yang telah ditentukan yakni: Anak retardasi mental sebanyak 3 orang dan perkembangan bahasa reseptive yang rendah. Lokasi dalam penelitian ini adalah Rumah Sakit Jiwa Tampan Pekanbaru. Adapun prosedur dalam penelitian dilakukan beberapa tahap yaitu : (1) tahap persiapan penelitian yang terdiri dari : Mengumpulkan dan mempelajari teori, Inform consent, membuat rancangan penelitian dan menyusun pedoman wawancara, melakukan proses screening. (2). Tahap pelaksanaan yang terdiri dari : pengambilan data awal sebelum penerapan, membuat rancangan program penerapan, pelaksanaan program penerapan dan pengambilan data setelah penerapan . 
Metode analisis data Analisa terhadap data pengamatan sangat dipengaruhi oleh kejelasan mengenai apa yang ingin diungkapkan peneliti melalui pengamatan yang dilakukan. Patton (dalam Poerwandari, 2001), menjelaskan bahwa proses analisis dapat melibatkan konsepkonsep yang muncul dari perilaku subjek penelitian sendiri maupun konsep yang dikembangkan oleh peneliti untuk menjelaskan fenomena yang dianalisis. Analisa data yang digunakan dalam penelitian ini adalah secara deskriptif, yaitu menganalisa subjek penelitian pada setiap sesi yang diikuti dengan analisa keseluruhan proses pelaksanaan terapi.

\section{HASIL DAN PEMBAHASAN}

Hasil Metode Focused Stimulation yang telah disusun oleh peneliti untuk kemampuan bahasa resepetive pada anak Retardasi Mental. Hasil dari penelitian ini di lihat dari perbandingan observasi sebelum terapi dan sesudah terapi, wawancara sebelum terapi dan sesudah terapi serta pelaksanaan penerapan metode focused simulation sebelum terapi pada hasil base line, proses pelaksaaan dan hasil evaluasi yaitu setelah penerapan metode focused stimulation.

Perbandingan hasil penerapan juga dapat di lihat juga dari hasil wawancara sebelum dan sesudah penerapan. Pada subjek FA, ibunya mengatakan bahwa di usia FA yang sudah 12 tahun seperi ini, bicaranya masih tidak jelas, kadang kadang hanya mengulang kata kata yang sebutkan orang lain. FA juga masih susah di beri pengerian. Beberapa nama benda kadang FA sudah mengetahui, namun lebih hanya dapa menyebutkan saja tanpa mengetahui fungsi dari benda tersebut. Selain itu FA tidak bisa fokus jika mengerjakan sesuatu. Menurut ibu FA setelah menjalani terapi telah terjadi perubahan dalam berbicara, meskipun tidak terlalu banyak. Beberapa benda seperti sendok, piring, garpu FA dapat menyebutkannya, namun kadang masih sering lupa setelah di ajarkan lagi. Di sisi lain pada ketrampilan sehari hari, FA juga belum mengetahui fungsi uang, belum mengetahui rentang waktu. Dalam wawancara dengan terapis FA, disebutkan bahwa perkembangan bahasa reseptif dan bahasa ekpresif masih rendah. Ketika diajarkan tentang pengenalan benda ada, beberapa benda dapat disebutkan, namun ketika di tanya kembali FA tidak dapat menyebutkannya kembali. Pada pelaksanaan penerapan focused stimulation pada FA, di awal proses terapi belum terlihat perubahan yang signifikan. Ketika proses pengenalan nama benda di tunjukkan berupa gambar seperti gambar piring, sendok, garpu, gelas FA tidak dapat menyebutkan nama benda tersebut meskipun sudah diajarkan beberapa kali. Kemudian ketika di beri stimulasi berupa benda asli kadang FA dapat menyebutkannya. Ketika terapis coba mengecoh dengan mengalihkan benda lain, kemudian menanyakan kembali benda yang di tunjukkan di gambar 
FA tidak dapa menjawabnya. Pada akhir pelaksanaan terapi, perkembangan bahasa reseptive belum meningkat secara signifikan. FA hanya meningkat 2 poin di banding dengan hasil baseline yang berjumlah 3 poin.

Wawancara juga dilakukan pada ibu FR. Ibunya mengatakan bahwa FR mengalami keterlambatan berbicara, ia tidak memahami apa yang disampaikan orang lain. FR hanya mengulang kata yang disebutkan. Dalam kesehariannya motoriknya juga belum berkembang baik. Ia belum dapat memgang pinsil dengan baik. Ia juga belum memahami nilai ukar uang dan waktu. Namun setelah diterapi FR sudah mulai paham instruksi. Sudah mulai mengetahui nama nama benda dan fungsinya. Pada wawancara terapis juga mengatakan bahwa FR di diagnosa mengalami mental retardasi. Ia belum mampu mengelompokkan benda. Jika bermain FR tidak memainkan mainan sesuai fungsinya. Perkembangan bahasanya juga sangat lambat. Ia tidak memahami instruksi tugas yang diberikan, jika diberi informasi berupa kalimat panjang ia tidak memahaminya. Namun setelah dilakukan terapi mengalami perubahan yang cukup signifikan. Sudah mulai memahami perintah. Dapat menyebutkan nama nama benda yang ditunjukkan melalui gambar. Jika gambar tersebut dialihkan dalam benda yang asli FR cukup dapat menjawabnya dengan baik. FR juga sudah mulai dapat berkomunikasi dua arah secara sederhana.

Hasil peneltitian ini juga dapat dilihat dari perbandingan sebelum penerapan focused stimulation dan setelah penerapan focused stimulation . pelaksanaan penerapan dilakukan sebanyak 10 kali sesi termasuk di dalamnya hasil baseline dan evaluasi hasil penerapan. Hal ini sesuai yang disebukan oleh Tyndall - Lind dan Landret, 2001, dalam Mukhtar, Y. 2005 bahwa pada banyak kasus, pemberian program jangka pendek ( intensive short term therapy) selama 9-24 jam (dalam 6 - 12 pertemuan) cukup efektif untuk membantu memperbaiki perilaku anak-anak dengan berbagai masalah.

Tabel 1. Hasil Baseline (sebelum penerapaan ) FA

\begin{tabular}{|c|c|c|c|c|c|c|}
\hline \multirow[b]{2}{*}{ No } & \multirow[b]{2}{*}{ Materi tes } & \multirow{2}{*}{ Stimulus } & \multicolumn{3}{|c|}{$\begin{array}{rr}\text { Respon } \\
\end{array}$} & \multirow[b]{2}{*}{ Total Nilai } \\
\hline & & & $\begin{array}{c}\text { Kesempatan } \\
1\end{array}$ & $\begin{array}{c}\text { Kesempatan } \\
2\end{array}$ & $\begin{array}{c}\text { Kesempatan } \\
3\end{array}$ & \\
\hline 1 & $\begin{array}{l}\text { Kartu gambar piring, } \\
\text { gelas, sendok, garpu }\end{array}$ & piring & 0 & 0 & 0 & 0 \\
\hline 2 & $\begin{array}{l}\text { Kartu gambar piring, } \\
\text { gelas, sendok, garpu }\end{array}$ & gelas & 0 & 0 & 1 & 1 \\
\hline 3 & $\begin{array}{l}\text { Kartu gambar piring, } \\
\text { gelas, sendok, garpu }\end{array}$ & Sendok & 0 & 0 & 1 & 1 \\
\hline 4 & $\begin{array}{l}\text { Kartu gambar piring, } \\
\text { gelas, sendok, garpu }\end{array}$ & Garpu & 0 & 1 & 0 & 1 \\
\hline
\end{tabular}


Pada pengambilan data baseline terlihat kemampuan bahasa reseptive FA memiliki skor total 3. Pada materi tes 1 FA sama sekali tidak memberi respon jawaban atas stimulus yang diberikan. Kemudian pada materi tes selanjutnya FA dapat memberi respon namun tidak menjawab pada semua kesempatan, hanya pada beberapa kesempatan memberikan respon dengan jawaban yang benar.

\section{Tabel 2. Hasil Evaluasi (Setelah Penerapaan ) FA}

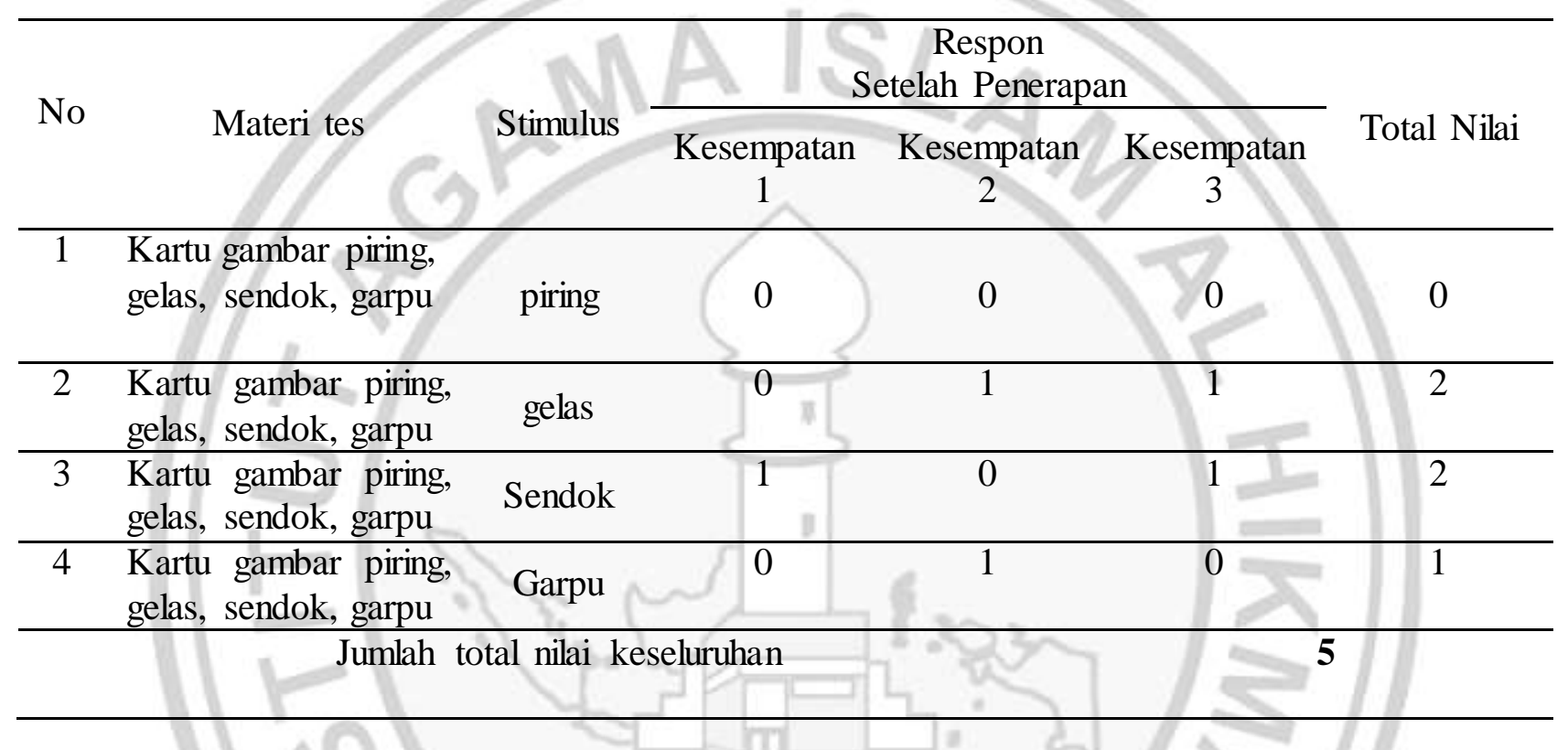

Berdasarkan hasil tabel perbandingan dapat disimpulkan bahwa terjadi peningkatan kemampuan bahasa reseptive pada subjek FA. Pada hasil baseline subjek FA mendapat 3 poin. Pada materi tes pertama subjek FA sama sekali tidak dapat menjawab pertanyaan atau gambar yang diajukan oleh terapis. Selanjutnya dapat menjawab pada materi 2 dan 3 sehingga subjek FA mendapat poin 3 . Setelah pelaksanaan metode focused stimulation sebanyak 8 kali terjadi peningkatan meskipun hanya 2 poin. Jumlah poin subjek FA setelah dilakukan metode focused stimulation menjadi 5 poin.

Tabel 3. Hasil Baseline (sebelum penerapan) FR

\begin{tabular}{ccccccc}
\hline \multirow{2}{*}{ No } & Materi tes & Stimulus & & \multicolumn{4}{c}{ Respon } & Kesempatan \\
\cline { 3 - 6 } & & & & $\begin{array}{c}\text { Kesempatan } \\
2\end{array}$ & $\begin{array}{c}\text { Kesempatan } \\
3\end{array}$ & Total Nilai \\
\hline 1 & $\begin{array}{l}\text { Kartu gambar piring, } \\
\text { gelas, sendok, garpu }\end{array}$ & piring & 1 & 0 & 0 & 1 \\
\hline 2 & Kartu gambar piring, & gelas & 0 & 1 & 0 & 1 \\
\hline
\end{tabular}




\begin{tabular}{|c|c|c|c|c|c|c|}
\hline & gelas, sendok, garpu & & & & & \\
\hline 3 & $\begin{array}{l}\text { Kartu gambar piring, } \\
\text { gelas, sendok, garpu }\end{array}$ & Sendok & 1 & 0 & 0 & 1 \\
\hline 4 & $\begin{array}{l}\text { Kartu gambar piring, } \\
\text { gelas, sendok, garpu }\end{array}$ & Garpu & 0 & 0 & 1 & 1 \\
\hline \multicolumn{6}{|c|}{ Jumlah total nilai keseluruhan } & 4 \\
\hline
\end{tabular}

Pada pengambilan data baseline terlihat kemampuan bahasa reseptive FR memiliki skor total 4. Pada semua materi yang disajikan, FR dapat memberikan respon yang benar namun hanya pada 1 kesempatan, artinya tidak menjawab benar pada seluruh kesempatan yang diberikan.

\section{Tabel 4. Hasil Evaluasi (setelah penerapaan ) FR}

\begin{tabular}{|c|c|c|c|c|c|}
\hline \multirow{2}{*}{ No } & & & $\begin{array}{l}\text { Respon } \\
\text { ah Pene }\end{array}$ & & \multirow{2}{*}{$\begin{array}{l}\text { Total } \\
\text { Nilai }\end{array}$} \\
\hline & Stimulus & $\begin{array}{c}\text { Kesempatan } \\
1\end{array}$ & $\underset{2}{\text { Kesempatan }}$ & $\begin{array}{c}\text { Kesempatan } \\
3\end{array}$ & \\
\hline 1 & $\begin{array}{l}\text { Kartu gambar piring, } \\
\text { gelas, sendok, garpu }\end{array}$ & 17 & 0 & 1 & 2 \\
\hline 2 & $\begin{array}{l}\text { Kartu gambar piring, } \\
\text { gelas, sendok, garpu }\end{array}$ & 0 & 1 & $1=$ & 2 \\
\hline 3 & $\begin{array}{l}\text { Kartu gambar piring, } \\
\text { gelas, sendok, garpu }\end{array}$ & 1 & 0 & 0 & 1 \\
\hline 4 & $\begin{array}{l}\text { Kartu gambar piring, } \\
\text { gelas, sendok, garpu }\end{array}$ & 0 & 1 & & 2 \\
\hline
\end{tabular}

Berdasarkan hasil tabel perbandingan dapat disimpulkan bahwa terjadi peningkatan kemampuan bahasa reseptive pada subjek FR. Pada hasil baseline subjek FR mendapat 4 poin. Pada materi tes pertama subjek FR dapat menjawab pertanyaan atau gambar yang diajukan oleh terapis meskipun hanya 1 poin. Selanjutnya dapat menjawab pada materi 2,3 dan 4 sehingga subjek FR mendapat poin 4 . Setelah pelaksanaan metode focused stimulation sebanyak 8 kali terjadi peningkatan meskipun hanya 3 poin. Jumlah poin subjek FR setelah dilakukan metode focused stimulation menjadi 7 poin. 
Tabel 5. Hasil Baseline (sebelum penerapan)FM

\begin{tabular}{ccccccc}
\hline & & & \multicolumn{4}{c}{ Respon } \\
\cline { 3 - 6 } No & Materi tes & Stimulus & $\begin{array}{c}\text { Kesempatan } \\
1\end{array}$ & $\begin{array}{c}\text { Kesempatan } \\
2\end{array}$ & $\begin{array}{c}\text { Kesempatan } \\
3\end{array}$ & Total Nilai \\
\hline 1 & $\begin{array}{l}\text { Kartu gambar piring, } \\
\text { gelas, sendok, garpu }\end{array}$ & piring & 0 & 0 & 1 & 1 \\
\hline 2 & $\begin{array}{l}\text { Kartu gambar piring, } \\
\text { gelas, sendok, garpu }\end{array}$ & gelas & 1 & 0 & 0 & 1 \\
\hline 3 & $\begin{array}{l}\text { Kartu gambar piring, } \\
\text { gelas, sendok, garpu }\end{array}$ & Sendok & 1 & 0 & 1 & 2 \\
\hline 4 & $\begin{array}{l}\text { Kartu gambar piring, } \\
\text { gelas, sendok, garpu }\end{array}$ & Garpu & 1 & 0 & 0 & 1 \\
\hline & Jumlah total nilai keseluruhan & 5 \\
\hline
\end{tabular}

Pada pengambilan data baseline terlihat kemampuan bahasa reseptive FM memiliki skor total 5. Pada semua materi yang disajikan, F5 dapat memberikan respon yang benar. Dari kesempaan yang diberikan rata rata FM hanya mampu menjawab benar pada satu kesempatan. Hanya pada materi ke 3 yakni pada kartu gambar piring, gelas, sendok, garpu dengan stimulus sendok FM dapat menjawab benar dengan 2 kali kesempatan.

Tabel. 6 Hasil Evaluasi (setelah penerapaan ) FR

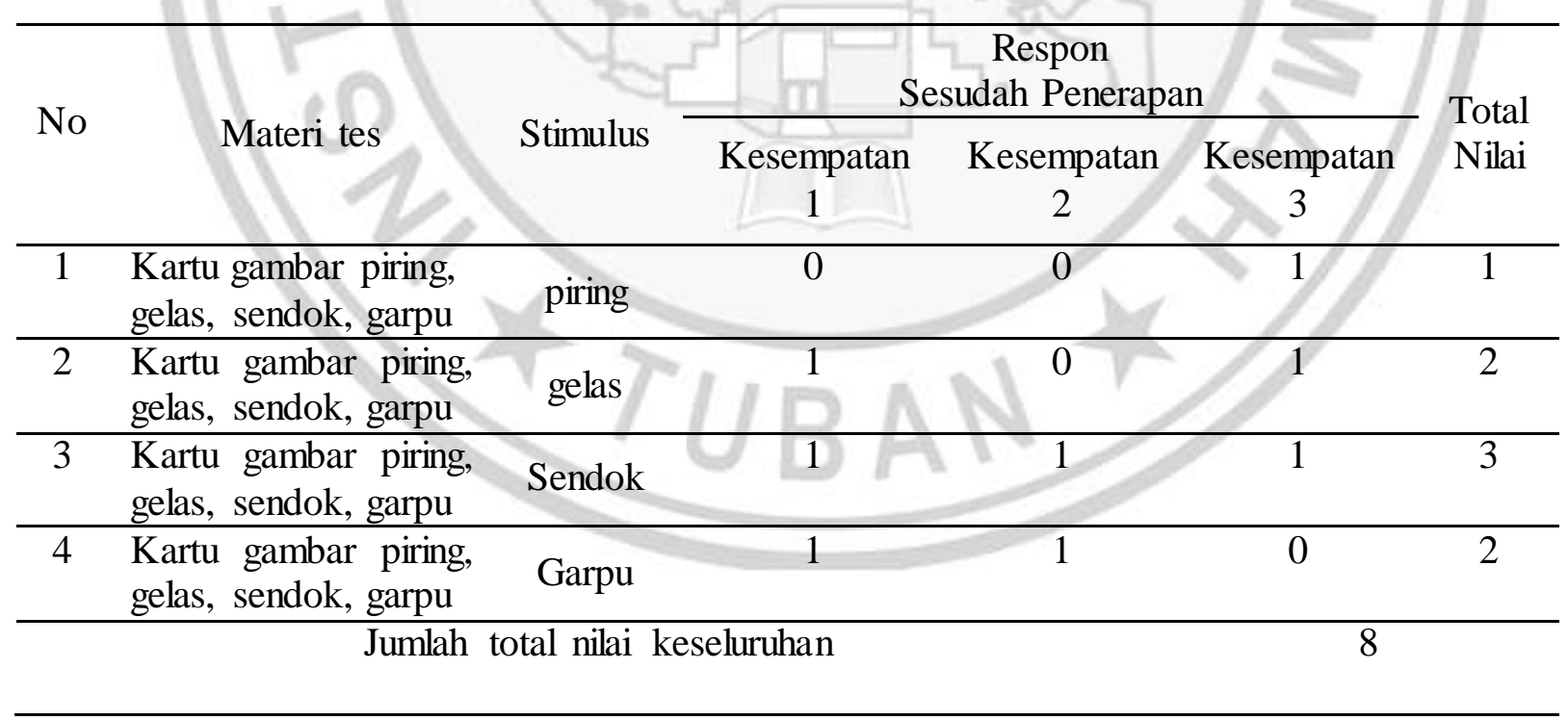

Berdasarkan hasil tabel perbandingan dapat disimpulkan bahwa terjadi peningkatan kemampuan bahasa reseptive pada subjek FM. Pada hasil baseline subjek FM mendapat 5 poin. Setelah pelaksaan metode Focused Stimulation sebanyak 8 kali terjadi peningkatan 
meskipun hanya 2 poin. Jumlah poin subjek FM setelah dilakukan metode focused stimulation menjadi 8 poin.

Pada penelitian ini, untuk meningkatkan kemampuan bahasa reseptive pada anak retardasi mental dilakukan dengan metode focused stimulation. Hal ini juga dilakukan pada subjek FA, FR dan FM. Menurut (Weismer \& Robertson, 2006 dalam Rhea Paul 2012), metode focused stimulation ini mengatur konteks interaksi sehingga anak anak tergoda untuk menghasilkan ucapan yang telah ditargetkan. Anak anak dibantu dengan menyediakan model model target yang ditentukan dalam konteks komunikatif yang bermakna, biasanya dilakukan berupa permainan. pendekatan ini sangat efektif untuk meningkatkan pemahaman bentuk, serta produksi kata kata.

Pelaksanaan metode focused stimulation ini dilaksanakan sebanyak 10 kali sesi, termasuk di dalamnya pengambilan data baseline dan tahap evaluasi. Hal ini sesuai yang dikatakan Tyndall - Lind dan Landret, 2001, dalam Mukhtar, Y. 2005 bahwa pada banyak kasus, pemberian program jangka pendek (intensive short term therapy) selama 9-24 jam (dalam 6 - 12 pertemuan ) cukup efektif untuk membantu memperbaiki perilaku anak-anak dengan berbagai masalah. Levy juga menemukan dalam penelitiannya bahwa penurunan dorongan agresifitas, konflik internal, dan perilaku yang tidak tepat baru berhasil setelah 10 sesi (dalam Jhonson, 2001, dalam Mukhtar, Y. 2005) .

Pada pelaksanaan tahap baseline, penilaian perkembangan kemampuan bahasa reseptive subjek dilakukan dengan menggunakan lembar kerja. Dari hasil baseline terlihat bahwa FA mendapatkan poin 3, FR mendapatkan poin 4 dan FM mendapatkan poin 5. Setelah dilakukan penerapan metode focused stimulation terjadi peningkaan kemampuan bahasa resptive pada ke tiga subjek. Dalam pelaksanan 8 kali terapi setelah dilakukan evaluasi pada sesi ke 10 terjadi peningkatan jumlah poin pada subjek FA menjadi 5 poin, namun peningkaan tersebut tidak signifikan, karena hanya meningkat 2 poin dari jumlah awal sebelum terapi. Hal ini disampaiakan oleh terapis. Metode ini bukan berarti tidak berhasil pada subjek FA, namun untuk subjek FA, penerapan metode focused stimulation tidak cukup hanya 8 kali terapi. Untuk hasil yang lebih baik lagi subjek FA perlu menambah beberapa sesi terapi lagi.

Penerapan focused stimulation pada subjek FR terjadi perubahan yang signifikan. Ini dapat dilihat dari perbandingan hasil baseline dan evaluasi. Pada pelaksanaan baseline FR 
mendapat nilai 4 poin. Setelah dilakukan terapi sebanyak 8 kali terjadi peningkatan kemampuan bahasa FR, yakni menjadi 7 poin. Terjadi peningkatan 3 poin selama masa terapi. Hal ini menunjukkan bahwa metode ini cukup efektif diterapkan untuk kemampuan bahasa reseptive pada subjek FR. Demikian juga pada subjek FM, pada hasil baseline mendapat nilai 5 poin. Setelah dilakukan metode focused stimulation terjadi peningkatan menjadi 8 poin. Terjadi peningkaan yang cukup signifikan peningkaan kemampuan bahasa reseptive pada subjek FM.

Berdasarkan pelaksaaan penerapan metode focused stimulation yang dilakukan sebanyak 10 kali dengan tahapan baseline, pelaksaaan terapi dan evaluasi, terjadi peningkatan kemampuan bahasa reseptive pada subjek. Meskipun pada subjek FA hanya terjadi peningkatan 2 poin namun secara keseluruhan terjadi peningkatan. Dengan demikian dapat disimpulkan penerapan metode focused stimulation yang diterapkan sebanyak 10 kali tersebut efektive untuk kemampuan bahasa reseptive pada anak retardasi mental. Hal ini sesuai yang disebutkan oleh Tyndall - Lind dan Landret, 2001, dalam Mukhtar, Y. 2005 bahwa pada banyak kasus, pemberian program jangka pendek (intensive short term therapy) selama 9-24 jam (dalam 6 - 12 pertemuan ) cukup efektif untuk membantu memperbaiki perilaku anakanak dengan berbagai masalah.

\section{PENUTUP}

\section{Simpulan}

Dengan menggunakan metode focus stimulation terjadi peningkatan kemampuan bahasa reseptive pada anak reardasi mental. Metode focus stimulation tepat digunakan unuk kemampuan bahasa reseptive pada anak retardasi mental.

\section{Saran}

Bagi peneliti lainnya agar dapat mengembangkan variabel-variabel lainnya agar semakin banyak ditemukan metode lain untuk kemampuan bahasa reseptive pada anak Retardasi Mental.

\section{DAFTAR PUSTAKA}

Akhmad Mukhlis, 2016, metakomunikasi anak usia dini: analisis dari permainan social berpura-pura,

Pontianak, Book One

Internasional

Prooceeding Seminar "Pengembangan Potensi Anak Usia Dini" 
DSM IV. (1995). Diagnostic and Statistical Manual of Mental Disorders. Fourth Edition. Washington DC: APA

Husain Junus (1996). Seputar jurnalistik. Solo: CV Aneka

Minakshi Vashist, dkk, 2011, Epidemiology of Severe Mental Retardation, IJBNST (2011), 1(1):32-

36, ISSN: 2250-0952

Moleong, L.J. (2005). Metodologi penelitian kualitatif (Cet.13). Bandung: PT. Remaja Rosdakarya.

Wenar, C. and Kerig, P. 2006. Developmental Psychopathology (from infancy through adolescence).

New York: McGraw-Hill

Oliver von Bohlen und Halbach, 2010, Dendritic spine abnormalities in mental retardation, Received: 14 September 2010 / Accepted: 4 October 2010 / Published online: 16 November 2010 \# Springer-Verlag 2010

Yulidar, 2017, Buku Ajar Dislogia, Akademi Terapi Wicara Yayasan Bina Wicara, Jakarta.

Rohmani Nur Indah, 2017, Gangguan Berbahasa Kajian pengantar, Malang, UIN Maliki Press

Peraturan Menteri kesehatan Republik Indonesia nomor 81 tahun 2014 tentang standar pelayanan terapi wicara

Poerwandari, K. (2001). Pendekatan kualitatif untuk penelitian perilaku manusia. Fakultas Psikologi, Universitas Indonesia : Lembaga Pengembangan Sarana Pengukuran dan Pendidikan Psikologi (LPSP3).

Field, J. 2003. Psycholinguistics: a Resource Book for Students. New York: Routledge

Rhea Paul, 2012, Languange Disorder from infancy through Adolescence listening speaking reading writing and communicating fourth edition, Mosby, an imprint of Elsevier Inc, ISBN: 978-0323-07184-0

Paul Fletcher dan Jon F. Miller, 2005, developmental theory and language disorder, Amsterdam_/Philadelphia , John Benjamins Publishing Company

Soetjiningsih. 2002. Tumbuh Kembang Anak. Jakarta:EGC

Wong, D. L, 2004, Pedoman Klinis Keperawatan Pediatrik, EGC, Jakarta

Wahidmurni dan Nur Ali. 2008. Penelitian Tindakan Kelas. Malang: UM PRESS dst. 